\title{
PERSEPSI PESERTA PELATIHAN DASAR TERHADAP PENGGUNAAN QUIZIZZ SEBAGAI METODE EVALUASI PEMBELAJARAN
}

\author{
Url Jurnal: https://uia.e-journal.id/akademika/article/1228 \\ DOI : https://doi.org/10.34005/akademika.v10i01. 1228
}

\author{
Submitted: 2021-02-09 Reviewed: 2021-05-12 Published: 2021-05-30 \\ Marsye Fera Kalahatu \\ Badan Pengembangan Sumber Daya Manusia, Provinsi Maluku \\ kalahatumarsyefera@gmail.com
}

\begin{abstract}
Quizizz is a web tool for creating interactive quiz games for use in classroom learning. It is very easy to use, interactive quizzes are made by having up to 5 answer choices including the correct answer. Evaluation with the quizizz method is used to measure the understanding of basic training participants before and after the learning process. With this quizizz method, training participants will enjoy evaluating learning more, because this method is as fun as playing games. But of course it cannot be denied that every application has advantages and disadvantages, including this quizizz application. The use of this quizizz application online is very dependent on the availability of the internet network. This paper describes the perceptions of basic training participants (Latsar) on the use of quizizz as a learning evaluation method, especially in anti-corruption training. The learning evaluation using quizizz was very effective, where the pre-test results related to the participants' understanding of anti-corruption material were $44 \%$, and the post-test results increased to $71 \%$ or an increase of $27 \%$. That means that the quizizz learning evaluation method is able to improve the results of the evaluation, concentration and motivation of the participants when they are in the learning evaluation process.
\end{abstract}

Keywords: quizizz, learning evaluation method, basic exercises

\begin{abstract}
Abstrak: Quizizz merupakan sebuah web tool untuk membuat permainan kuis interaktif yang digunakan dalam pembelajaran di kelas. Penggunaannya sangat mudah, kuis interaktif dibuat dengan memiliki hingga 5 pilihan jawaban termasuk jawaban yang benar. Evaluasi dengan metode quizizz ini digunakan untuk mengukur pemahaman peserta pelatihan dasar sebelum dan sesudah proses pembelajaran. Dengan metode quizizz ini, peserta pelatihan akan lebih enjoy dalam melakukan evaluasi pembelajaran, karena metode ini menyenangkan seperti bermain games. Namun tentu tidak dapat dipungkiri bahwa setiap aplikasi memiliki keunggulan dan kelemahan termasuk aplikasi quizizz ini. Penggunaan aplikasi quizizz ini secara online sehingga sangat tergantung dengan ketersediaan jaringan internet. Tulisan ini menjelaskan tentang presepsi peserta pelatihan dasar (Latsar) terhadap penggunaan quizizz sebagai metode evaluasi pembelajaran khususnya mata pelatihan anti korupsi. Evaluasi pembelajaran dengan menggunakan quizizz ini sangat efektif, dimana hasil pre test terkait pemahaman peserta terhadap materi anti korupsi sebesar $44 \%$, dan hasil post test meningkat menjadi $71 \%$ atau mengalami peningkatan sebesar $27 \%$. Itu berarti bahwa metode evaluasi pembelajaran dengan quizizz ini mampu meningkatkan hasil evaluasi, konsentrasi dan motivasi peserta ketika ada dalam proses evaluasi pembelajaran.
\end{abstract}

Kata Kunci : Quizizz, Metode Evaluasi Pembelajaran, Latihan Dasar

\section{PENDAHULUAN.}


Di tengah perkembangan teknologi informasi saat ini yang semakin pesat, disertai dengan tantangan revolusi industri 4.0 yang berdampak pada seluruh aspek kehidupan, termasuk di bidang pendidikan dan pelatihan, maka kompetensi literasi teknologi informasi komunikasi (TIK) di kalangan birokrasi menjadi penting untuk ditingkatkan. Teknologi informasi komunikasi menjadi komponen penting penyelenggaraan pemerintahan dan pembangunan. Kemampuan untuk meggunakan teknologi digital, alat komunikasi dan jaringan menjadi bagian yang tidak terpisahkan dalam pengukuran kompetensi bagi Aparatur Sipil Negara (ASN). Salah satu program dan strategi pemerintah yakni mewujudkan SMART ASN di tahun 2024, menjadi tugas dan tantangan bagi Lembaga Diklat Pemerintah untuk mewujudkan SMART ASN tersebut. Lembaga diklat yang di dalamnya terdapat widyaiswara memiliki peran penting dalam mewujudkan tujuan dimaksud. Penyelenggaraan pelatihan yang diselenggarakan oleh lembaga diklat harus mampu menghasilkan sumber daya manusia dalam hal ini ASN yang SMART dalam pelaksanaan tugas dan fungsinya. Tantangan yang dihadapi di era digital saat ini yaitu pembelajaran dalam pelatihan harus mampu menyesuaikan dengan kondisi birokrasi saat ini dimasa transisi menuju "Birokrasi Digital" dan karakteristik peserta pelatihan khususnya peserta pelatihan dasar CPNS yang adalah generasi milenial yang sangat familiar dengan perkembangan teknologi informasi dan komunikasi. Hal ini menjadi tantangan bagi widyaiswara atau fasilitator untuk harus menguasai teknologi yang berkembang saat ini sehingga dapat bersaing secara global dan menjadi pilar kemajuan bangsa terutama dalam meningkatkan kompetensi ASN. Widyaiswara atau fasilitator memiliki tanggungjawab untuk menciptakan pengajaran yang berkualitaas, dan menghasilkan peserta pelatihan yang profesional. Untuk menciptakan pengajaran yang berkualitas dalam pelatihan maka salah satu upaya yang ditempuh oleh widyaiswara atau fasilitator adalah dengan menerapkan metode dan strategi dalam pembelajaran yang efektif dan berbasis teknologi dan berbasis digital sehingga akan tercipta suasana belajar yang menarik dan menyenangkan di dalam ruangan kelas.

Pada setiap kegiatan pembelajaran seorang widyaiswara atau fasilitator harus melakukan penilaian atau evaluasi setelah materi yang disampaikan telah selesai. penilaian (evaluasi) bertujuan untuk mengukur persentase penguasaan atau pemahaman peserta pelatihan terhadap materi atau mata pelatihan yang diajarkan. Bentuk penilaian yang dilakukan tidak hanya berpatokan pada penilaian tertulis yang dijawab oleh peserta pelatihan dengan tulisan atau pun penilaian lisan yang dijawab dengan lisan atau bahkan menggunakan aplikasi yang relavan. Sistem penilaian yang baik akan mampu memberikan gambaran tentang kualitas pembelajaran sehingga mampu membantu widyaiswara atau fasilitator merencanakan metode dan strategi pembelajaran. Bagi peserta pelatihan sendiri, sistem penilaian yang baik akan memberikan motivasi untuk selalu meningkatkan kemampuannya. Metode evaluasi yan selama ini diterapkan masih bersifat manual atau konvensional dimana soal - soal yang akan diberkan kepada peserta dibuat, dicetak dan diperbanyak sesuai jumlah peserta. Metode secara manual atau konvensional ini tentu akan menimbulkan biaya dalam penerapnnya, selain itu metode ini dirasa tidak lagi relevan di era yang serba modern saat ini, metode secara manual atau konvensional juga tentu membosankan dan peluang bagi peserta untuk saling berbagi jawaban sangat besar, disamping itu, yang menjadi persoalan ketika menggunakan metode evaluasi secara manual atau konvensional yakni hasil evaluasi yang dilakukan tidak dapat diketahui secara langsung oleh peserta karena widyaiswara atau fasilitator harus memeriksa atau mengoreksi hasil evaluasi dari masing-masing peserta sementara proses pre dan post test itu hanya berlangsung dalam 1 hari pembelajaran. Metode evaluasi pembelajaran yang dapat diterapkan diantaranya quizizz, google classroom atau khahoot. Namun dengan berbagai kendala yang ditemui selama ini, maka salah satu metode evaluasi yang coba diterapkan dalam proses evaluasi pembelajaran pada pelatihan dasar yakni Quizizz. Nada dkk. (2020), menyatakan bahwa terdapat korelasi antara pengaruh interaksi media pembelajaran online (google classroom) dengan kecerdasan emosional terhadap hasil belajar. Ditambahkan Nada dkk. (2020) bahwa hasil belajar siswa lebih maksimal dibandingkan dengan menggunakan bahan ajar cetak. 
Menurut Wagner dan Hollenbeck. (1995) persepsi didefenisikan sebagai sebuah proses yang mana seseorang tersebut dapat memilih, mengelola, menyimpan, serta menginterpretasikan informasi-informasi yang telah dikumpulkan melalui kelima indera tersebut. Pendapat Robbins (2003), menyatakan persepsi merupakan sebuah proses yang ditempuh masing-masing individu untuk mengorganisasikan serta menafsirkan kesan dari indera yang anda miliki agar memberikan makna kepada lingkungan sekitar. Menurut Tiato dan Titik Trowulan. (2006) persepsi merupakan sebuah proses identifikasi atau pengenalan pada sesuatu hal yang mana menggunakan indera yang dimilikinya. Kesan yang diterima oleh individu ini akan sangat bergantung dari semua pengalaman yang sudah diperoleh melalui proses belajar, berpikir dan dipengaruhi faktor dari individu itu sendiri.

Menurut Peraturan Kepala Lembaga Administrasi Negara Republik Indonesia nomor 12 Tahun 2018, Pelatihan dasar CPNS adalah pendidikan dan pelatihan dalam masa prajabatan yang yang dilakukan secara terintegrasi untuk membangun integritas moral, kejujuran, semangat dan motivasi nasionalisme dan kebangsaan, karakter kepribadian yang unggul dan bertanggung jawab, dan memperkuat profesionalisme serta kompetensi bidang.

Secara umum Quizizz merupakan sebuah web tool untuk membuat permainan kuis interaktif yang digunakan dalam pembelajaran di kelas. Penggunaannya sangat mudah, kuis interaktif dibuat dengan memiliki hingga 5 pilihan jawaban termasuk jawaban yang benar. Quizizz merupakan salah satu inovasi media dalam kegiatan evaluasi pembelajaran. Banyak fitur yang bias digunakan seperti soal pilihan ganda, soal isian, maupun uraian. Menurut Citra dan Rosy (2020), menjelaskan bahwa quizizz adalah aplikasi pendidikan berbasis game yang membawa aktivitas multi pemain ke ruang kelas dan menjadikan pembelajaran dalam kelas lebih menyenangkan dan interaktif. Pendapat Wibawa dkk (2019) menyebutkan bahwa aplikasi quizizz mempunyai fitur yang secara umum dapat memfasilitas guru maupun peserta didik dalam proses pembelajaran. Hal tersebut menunjukan bahwa aplikasi quizizz bisa digunakan untuk inovasi pembelajaran.

Dalam Kamus Bahasa Indonesia dijelaskan metode adalah suatu cara kerja yang tersistem digunakan untuk mempermudah dalam melakukan berbagai pelaksanaan suatu kegiatan dalam mencapai tujuan yang telah di tentukan. Rosdy Ruslan (2003) berpendapat metode adalah aktivitas ilmiah yang masih berkenaan pada suatu cara kerja yang tersusun (Sistematis) di tujukan agar dapat memahami suatu subjek atau objek pada sebuah penelitian, sebagai salah satu cara untuk menemukan jawaban yang bisa di pertanggung jawabkan ilmiah serta keabsahannya. Menurut Ostle.(1975) metode memiliki arti suatu pengejaran terhadap sesuatu yang ingin di peroleh atau di capai (interelasi.)

Tyler dalam Arikunto (2016) mendefinisikan bahwa evaluasi pembelajaran merupakan sebuah proses pengumpulan data untuk menemukan sejauh mana, dalam hal apa, dan bagian mana tujuan pendidikan sudah tercapai. Evaluasi pembelajaran adalah suatu proses berkelanjutan tentang pengumpulan dan penafsiran informasi, dalam menilai (assessment) keputusan yang dibuat untuk merancang suatu sistem pembelajaran (Febriana, 2019). Sementara Purwanto. (2013) berpendapat bahwa Evaluasi pembelajaran adalah proses untuk mendapatkan data dan informasi yang diperlukan dalam menentukan sejauh mana dan bagaimana pembelajaran yang telah berjalan agar dapat membuat penilaian (judgement) dan perbaikan yang dibutuhkan untuk memaksimalkan hasilnya.

Penelitian sebelumnya oleh Suharsono (2020), tentang penggunaan aplikasi quizizz dalam pelatihan dasar CPNS Kemenkeu generasi milenial, menyimpukan bahwa banyak peserta yang setuju jika hasil pre dan post test dapat digunakan sebagai patokan pemberian nilai aktifitas. Sebagian peserta berpendapat bahwa pembelajaran menggunakan aplikasi quizizz dapat mengajarkan materi dalam modul lebih dari $80 \%$, selain itu $63 \%$ peserta mengatakan pembelajaran menggunakan quizizz menarik dan menyenangkan, $16 \%$ mengatakan lebih mudah memahami materi. Kekurangan menggunakan quizizz ini adalah ketergantungan terhadap Internet di tempat pembelajaran. Berdasarkan hasil penelitian terdapat banyak manfaat dan kelebihan pembelajaran dengan menggunakan quizizz sehingga ada baiknya pengajar menggunakan quizizz dalam pembelajaran.

Menurut Syaifulloh (2020), dengan judul penelitian pengembangan alat evaluasi menggunakan aplikasi quizizz pada pembelajaran IPS terpadu di MTS Negeri Malang, 
menurut guru mata Pelajaran IPS terpadu, alat evaluasi menggunakan quizizz ini cukup mudah untuk diterapkan serta dapat mempersingkat waktu pada saat proses peilaian. Guru juga merasa terbantu dengan dengan adanya alat evaluasi quizizz yang praktis dan inovatif.

Menurut Rahman dkk (2020), dengan judul penelitian penggunaan aplikasi quizizz sebagai media pemberian kuis dalam meningkatkan motivasi belajar mahasiswa menyimpulkan bahwa penggunaan apliaksi quizizz dapat dimanfaatkan sebagai media pemberian kuis kepada mahasiswa yang hasilnya sangat signifikan berpengaruh pada motivasi belajar mahasiswa. Penggunaan aplikasi quizizz sebagai media pemberian kuis meningkatkan motivasi belajar mahasiswa.

Sementara menurut Kusuma (2020), dalam penelitiannya yang berjudul efektifitas peggunaan aplikasi quizizz dalam pembelajaran daring fisika pada materi usaha dan energy kelas X MIPA di SMA Masehi Kudus Tahun Pelajaran 2019/2020, menyimpulkan bahwa penggunaan media quizizz pada pembelajaran daring kelas X MIPA di SMA Masehi Kudus terkait materi usaha dan energi yang dilakukan pada kegiatan penutup telah berjalan dengan baik sekali. Penggunaaan quizizz dalam pembelajaran daring kelas X MIPA di SMA Masehi Kudus sudah berjalan dengan efektif.

Dalam penelitian yang ditulis oleh sudihartono (2020) dengan judul penerapan quizizz dalam pelaksanaan penilaian pengetahuan peserta diklat di Badan Pengembangan Sumber Daya Manusia Daerah Provinsi Sumatera Selatan disampaikan bahwa secara komprehensif penilaian kemampuan kognitif, afektif, dan psikomotorik dinilai baik terhadap penerapan quizizz dalam pelaksanaan penilaian pada peserta pelatihan dasar CPNS di BPSDMD Provinsi Sumatera Selatan. Rata - rata kemampuan kognitif peserta Latsar CPNS mengalami peningkatan. Hal ini terlihat dari relatif kenaikan presentase perbandingan antara pre test dan post test yang menunjukan bahwa kemampuan kognitif peserta pelatihan dasar CPNS dapat ditingkatkan dengan melakukan evaluasi pebelajaran menggunakan quizizz sehingga layak untuk diterapkan dengan hasil yang lebih efektif dan efisien.

Penelitian sebelumnya yang dilakukan oleh Sugian Noor (2020) yang berjudul penggunaan quizizz dalam penilaian pembelajaran pada materi ruang lingkup biologi untuk meningkatkan hasil belajar siswa kelas X.6 SMA 7 Banjarmasin. Hasil penelitian menunjukan bahwa terjadi peningkatan hasil belajar sebesar $20 \%$. Peningkatan tersebut terjadi karena quizizz menjadikan penilaian menarik dan menyenangkan sehingga memotivasi peserta didik untuk berhasil. Berdasarkan uraian penelitian terdahulu, maka dapat disimpulkan bahwa quizizz adalah salah satu aplikasi yang dapat digunakan dalam penilaian atau evaluasi pembelajaran. Fitur quizizz yang bervariasi membuat peserta pelatihan merasa senang dan antusias ketika melakukan evaluasi. Hal ini menyebabkan peserta pelatihan termotivasi untuk bisa menyelesaikan evaluasi atau penilaian dengan hasil yang maksimal.

Berdasarkan latar belakang yang di sampaikan di atas maka penelitian ini terfokus pada penilaian persepsi peserta Pelatihan Dasar CPNS terhadap Penggunaan Quizizz Sebagai Metode Evaluasi Pembelajaran. Penelitian ini dibatasi pada persepsi peserta pelatihan dasar terhadap penggunaan Quizizz sebagai metode evaluasi pembelajaran khususnya pada mata pelatihan anti korupsi.

\section{METODE}

Penelitian ini menggunakan jenis penelitian kualitatif dengan metode analisis deskriptif. Menurut Sugiyono (2005: 21) menyatakan bahwa metode deskriptif adalah suatu metode yang digunakan untuk menggambarkan atau menganalisis suatu hasil penelitian tetapi tidak digunakan untuk membuat kesimpulan yang lebih luas. Tujuan dari penelitian deskriptif ini adalah untuk membuat deskripsi, gambaran, atau lukisan secara sistematis, faktual dan akurat mengenai fakta-fakta, sifat-sifat serta hubungan antar fenomena yang diselidiki. Dapat dikatakan bahwa penelitian deskriptif merupakan penelitian yang berusaha mendeskripsikan suatu gejala, peristiwa yang terjadi pada saat sekarang atau masalah aktual. 
Teknik analisis data yang digunakan dalam penelitian ini adalah statistik dekriptif persentase dengan tujuan untuk mengorganisasi dan menganalisis data agar memberikan gambaran secara teratur, ringkas, dan jelas mengenai suatu gejala, peristiwa atau keadaan, sehingga dapat ditarik pengertian atau makna tertentu.

Jenis data yang digunakan dalam penelitian ini yaitu data primer, dimana data yang diperoleh langsung dari sumber yaitu peserta pelatihan dasar CPNS melalui pengisian kuesioner secara online yang berkaitan dengan persepsi peserta terkait penggunaan quizizz sebagai metode evaluasi pembelajaran, selain itu data sekunder juga diperlukan berupa literatur atau artikel maupun jurnal yang terkait dengan penelitian.

Teknik pengumpulan data dilakukan dengan menggunakan kuesioner. Kuesioner merupakan teknik pengumpulan data yang dilakukan dengan cara memberikan seperangkat pertanyaan kepada responden untuk dijawab, dan bersifat tertutup. Kuesioner ini terdiri dari 10 pertanyaan terkait persepsi peserta terhadap penggunaan quizizz sebagai metode evaluasi pembelajaran. Kuesioner dalam penelitian tindakan kelas ini disebarkan sejak tanggal 12 - 16 Juni 2020 bagi seluruh peserta pelatihan dasar CPNS golongan II angkatan IX tahun 2020 kelas A dalam bentuk Google Form. Populasi pada penelitian ini adalah semua peserta CPNS Golongan II angkatan IX tahun 2020 kelas A sebanyak 30 orang dan sampelnya diambil seluruh populasi yakni 30 orang. Hasil pengolahan data kuesioner ditampilkan dalam bentuk diagram lingkaran, Diagram Batang, tabel dan grafik.

\section{HASIL}

Penelitian ini merupakan penelitian tindakan kelas yang dilakukan pada peserta pelatihan dasar CPNS Golongan II, hasil yang diperoleh dari hasil rangkuman persepsi peserta terhadap penggunaan quizizz sebagai metode evaluasi pembelajaran maka dapat dijabarkan sebagai berikut :

Tabel 1. Hasil Pre dan Post Test

\begin{tabular}{ccc}
\hline NO & PRE TEST & POST TES \\
\hline 1 & 2870 & 4350 \\
\hline 2 & 4580 & 4180 \\
\hline 3 & 2790 & 7110 \\
\hline 4 & 3400 & 3530 \\
\hline 5 & 3830 & 8060 \\
\hline 6 & 710 & 3720 \\
\hline 7 & 4550 & 6900 \\
\hline 8 & 4400 & 6930 \\
\hline 9 & 3200 & 4790 \\
\hline 10 & 4810 & 5880 \\
\hline 11 & 3380 & 5770 \\
\hline 12 & 2750 & 2610 \\
\hline 13 & 2270 & 6040 \\
\hline
\end{tabular}




\begin{tabular}{|c|c|c|}
\hline NO & PRE TEST & POST TES \\
\hline 14 & 0 & 0 \\
\hline 15 & 730 & 6180 \\
\hline 16 & 3690 & 6360 \\
\hline 17 & 2680 & 8810 \\
\hline 18 & 3610 & 8800 \\
\hline 19 & 1200 & 7110 \\
\hline 20 & 1260 & 4330 \\
\hline 21 & 3440 & 9080 \\
\hline 22 & 3240 & 3900 \\
\hline 23 & 2200 & 4420 \\
\hline 24 & 3750 & 5430 \\
\hline 25 & 2240 & 6120 \\
\hline 26 & 3550 & 5600 \\
\hline 27 & 2820 & 5290 \\
\hline 28 & 2530 & 5760 \\
\hline 29 & 4290 & 7020 \\
\hline
\end{tabular}

Dari 29 peserta pelatihan dasar CPNS Golongan II kelas A, yang mengikuti pre dan post test hanya 28 peserta. 1 peserta dengan nomor absen 14 mengalami kendala ketika sedang melakukan proses pre test yaitu smartphone yang digunakan mengalami gangguan system, sehingga peserta tersebut tidak dapat melanjutkan pre test, hal ini berakibat pada data yang ditampilkan peserta tersebut tidak memiliki hasil atau nilai pre maupun post test. Secara keseluruhan hasil pre dan post tes mengalami peningkatan sebesar $27 \%$. Pada Pre test digambarkan bahwa tingkat akurasi mencapai $44 \%$ dan pada post test mencapai $71 \%$. Hanya ada 1 peserta dengan nomor absen 12 yang mengalami penurun nilai dari pre ke post Test. Terlihat ada peningkatan pemahaman dan hasil pencapaian dari pre ke post test seperti pada gambar dibawah ini : 


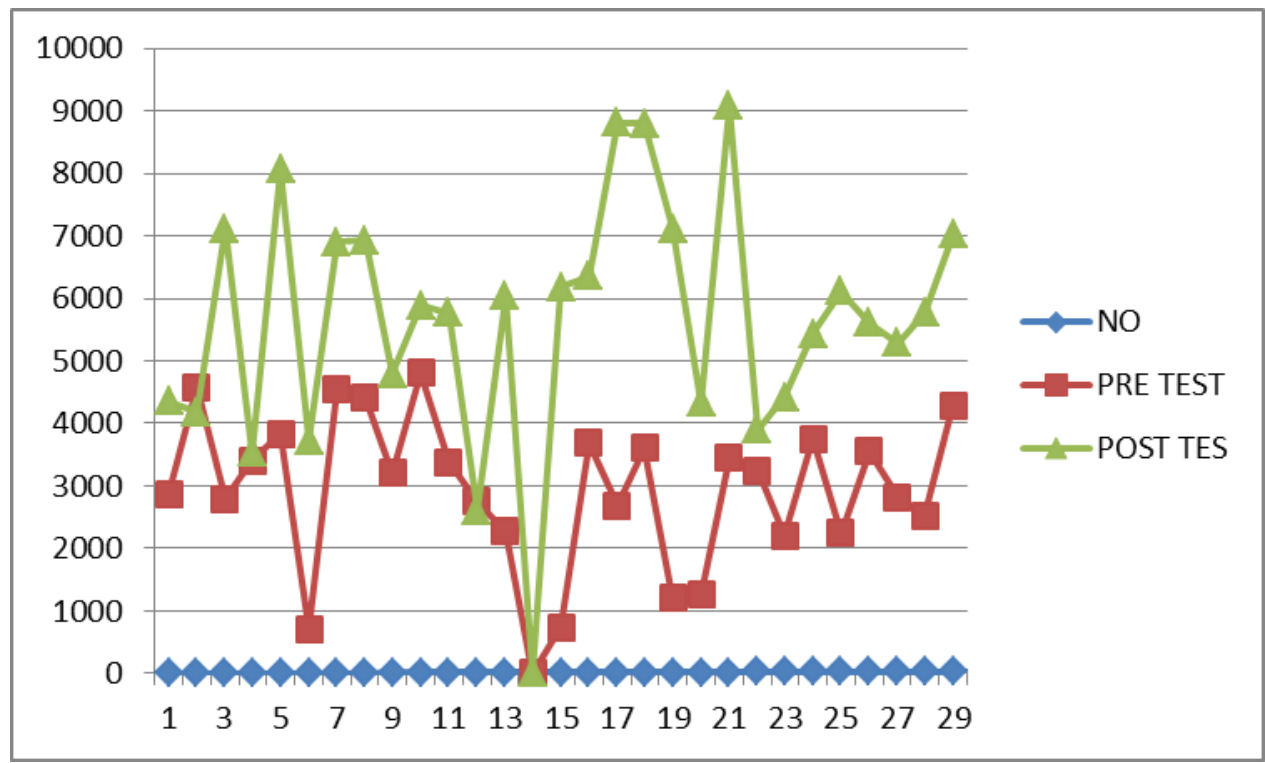

Gambar 1. Hasil Pre dan Post test dalam bentuk Grafik

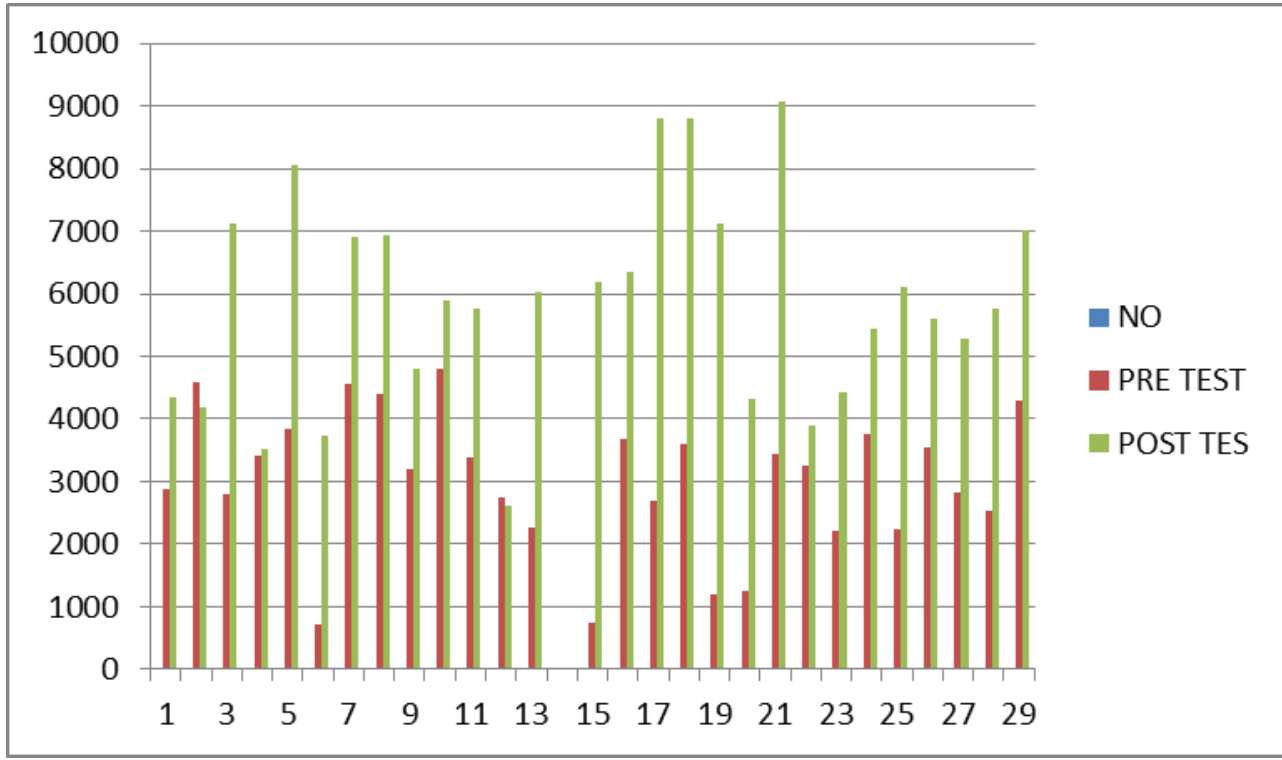

Gambar 2. Hasil Pre dan Post test dalam bentuk digram batang

Responden sebanyak 30 orang ini merupakan keseluruhan peserta pelatihan dasar CPNS Golongan II angkatan ke IX Tahun 2020 Kelas A dengan profil responden sebagai berikut :

Tabel. 2 Profil Responden

\begin{tabular}{|c|c|c|c|}
\hline No & Kategori & Presentas & \\
\hline \multirow[t]{2}{*}{1} & \multirow[t]{2}{*}{ Jenis Kelamin } & Perempuan & $82,7 \%$ \\
\hline & & Laki - Laki & $17,3 \%$ \\
\hline \multirow[t]{3}{*}{2} & \multirow[t]{3}{*}{ Usia } & 20 - 25 Tahun & $33,3 \%$ \\
\hline & & 26 - 30 Tahun & $60 \%$ \\
\hline & & 31 - 35 Tahun & $6,7 \%$ \\
\hline 3 & Tingkat Pendidikan & D3 & $100 \%$ \\
\hline \multirow[t]{2}{*}{4} & \multirow[t]{2}{*}{ Jabatan } & Tenaga Kesehatan & $76,8 \%$ \\
\hline & & $\begin{array}{l}\text { Pengelola Sistem } \\
\text { dan Jaringan }\end{array}$ & $3,3 \%$ \\
\hline
\end{tabular}




\begin{tabular}{|c|c|c|c|}
\hline & \multirow{2}{*}{$\begin{array}{l}\text { Pengelola Objek } \\
\text { Wlsata } \\
\text { Pengelola SIAK }\end{array}$} & $3,3 \%$ \\
\hline & & & $6,7 \%$ \\
\hline & & $\begin{array}{lr}\text { Pengelola } & \text { Pajak } \\
\text { dan } & \text { Retribusi } \\
\text { Daerah } & \end{array}$ & $3,3 \%$ \\
\hline & & Arsiparis & $3,3 \%$ \\
\hline & & Pengelola LPSE & $3,3 \%$ \\
\hline \multirow{7}{*}{\multicolumn{2}{|c|}{ Unit Kerja }} & Dinas Kesehatan & $76,8 \%$ \\
\hline & & $\begin{array}{l}\text { Dinas Kominfo dan } \\
\text { Persandian }\end{array}$ & $3,3 \%$ \\
\hline & & Dinas Pariwisata & $3,3 \%$ \\
\hline & & Dinas DUKCAPIL & $6,7 \%$ \\
\hline & & $\begin{array}{l}\text { Badan Pendapatan } \\
\text { Daerah }\end{array}$ & $3,3 \%$ \\
\hline & & $\begin{array}{l}\text { Badan } \\
\text { Perpustakaan dan } \\
\text { Kearsip Daerah }\end{array}$ & $3,3 \%$ \\
\hline & & $\begin{array}{l}\text { Bagian Pengadaan } \\
\text { Barang dan Jasa }\end{array}$ & $3,3 \%$ \\
\hline
\end{tabular}

Persepsi peserta tentang penggunaan quizizz sebagai metode evaluasi pembelajaran dapat diuraikan sebagai berikut :

Sebanyak 14 orang atau mencapai $46,7 \%$ belum pernah manggunakan Quizizz sebelumnnya, sebagai metode evaluasi, dan sebanyak 16 orang atau mencapai $53,3 \%$ pernah menggunakan Quizizz sebelumnya.

Apakah Sebelumnya anda pernah menggunakan Aplikasi Quiziz sebagai Metode Evaluasi?

30 tanggapan

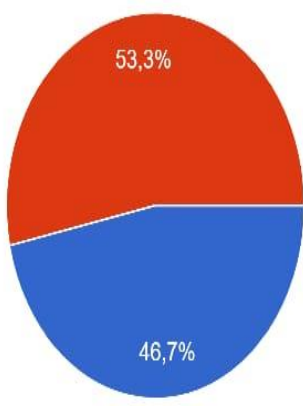

Tidak Pernah

Pernah

Sering

Gambar 3. Presentase pengalaman terkait penggunaan Aplikasi Quizizz

Dari 30 responden yang menyatakan setuju adalah sebanyak 12 orang atau mencapai $43,3 \%$ dan sebanyak 17 orang menyatakan sangat setuju tau mencapai $56,7 \%$ untuk melakukan evaluasi dengan menggunakan Quizizz. 
Apakah Anda setuju untuk melakukan Evaluasi dengan menggunakan Quizizz?

30 tanggapan

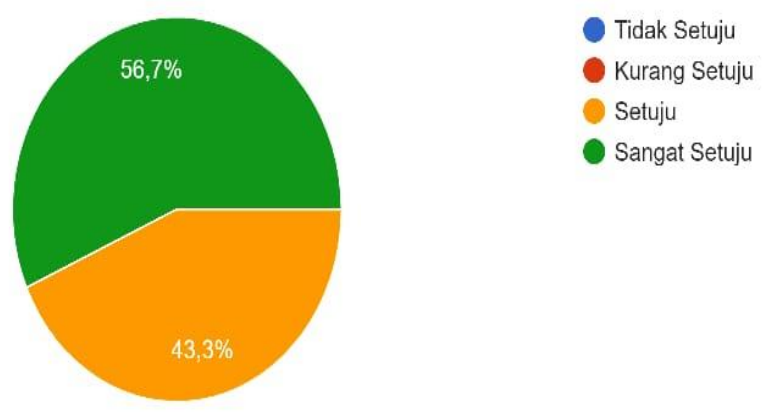

Gambar 4. Persepsi peserta tentang evaluasi pembelajaran dengan aplikasi quizizz

Menurut 20 responden atau mencapai $66,7 \%$ berpendapat bahwa penerapan metode evaluasi dengan Quizizz sangat efektif, sebanyak 8 responden atau mencapai $26,7 \%$ berpendapat efektif dan sebanyak 2 responden atau mencapai 6,6\% berpendapat cukup efektif.

Menurut anda apakah Penerapan Metode Evaluasi dengan Quiziz sangat efektif ?

30 tanggapan

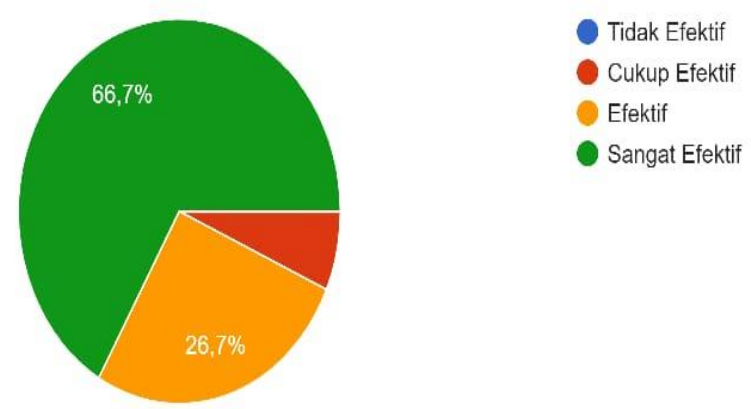

\section{Gambar 5. Persepsi peserta terkait efektivitas penggunaan aplikasi quizizz dalam evaluasi pembelajaran}

Metode evaluasi dengan Quizizz ini lebih efisien dari segi waktu dibandingkan dengan metode evaluasi secara manual. Hal tersebut terbukti dengan pendapat responden sebanyak 21 orang atau mencapai $70 \%$ berpendapat metode evaluasi dengan Quizizz ini sangat efisien, 6 orang atau mencapai $20 \%$ berpendapat efisien dan dan 3 responden atau mencapai $10 \%$ berpendapat cukup efisien. 
Menurut Anda apakah Metode Quiziz ini Efisien dari segi Waktu dibandingkan dengan Evaluasi secara manual?

30 tanggapan
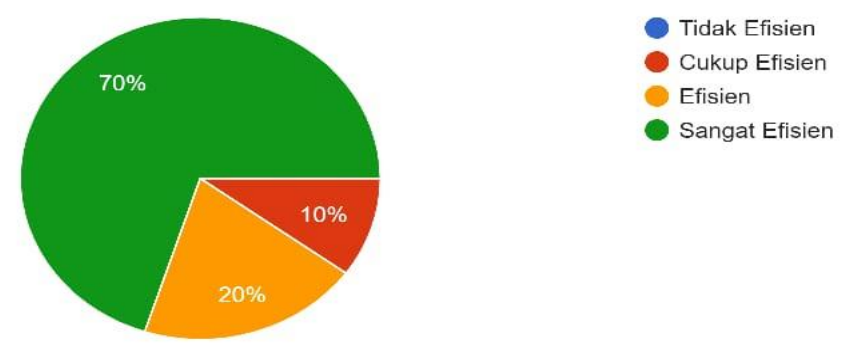

Gambar 6. Persepsi peserta terkait efisiensi penggunaan quizizz dalam evaluasi pembelajaran

Dalam penerapannya Quizizz sangat mudah digunakan atau dioperasikan hal ini sesuai dengan pendap responden sebanyak 23 Orang atau mencapai 76,7\% menyatakan bahwa Quizizz Sangat mudah digunakan dan 7 Orang atau mencapai $23.3 \%$ menyatakan Quizizz mudah digunakan atau dioperasikan.

Menurut anda apakah Penerapan Metode Evaluasi dengan Quiziz mudah digunakan/dioperasikan?

30 tanggapan

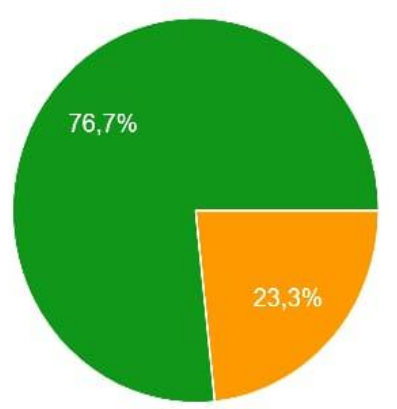

Tidak Mudah

Cukup Mudah

Mudah

Sangat Mudah

\section{Gambar 7. Persepsi peserta terkait aksesibilitas menggunakan quizizz}

Menurut pendapat dari 21 responden atau mencapai 70\% meyatakan bahwa Qiuizizz merupakan metode evaluasi yang sangat menyenangkan dan 9 responden atau $30 \%$ berpendapt metode ini menyenangkan. 
Menurut anda apakah Penerapan Metode Evaluasi dengan Quiziz sangat menyenangkan?

30 tanggapan

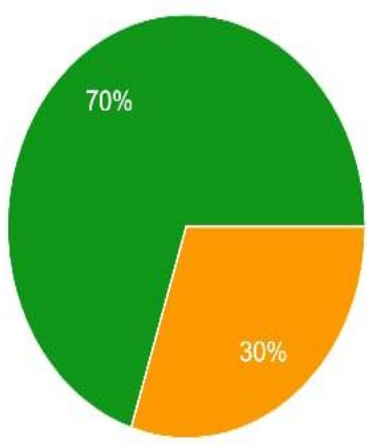

Tidak Menyenangkan

Cukup Menyenangkan

Menyenangkan

Sangat Menyenangkan

Gambar 8. Persepsi peserta terkait kepuasan menggunakan aplikasi quizizz

Dari 30 responden semunya atau mencapai $100 \%$ berpendapat bahwa dengan menggunakan Quizizz tujuan yang diharapkan dari evaluasi dapat tercapai.

Menurut Anda apakah dengan menggunakan Quiziz ini Tujuan Evaluasi dapat tercapai?
30 tanggapan

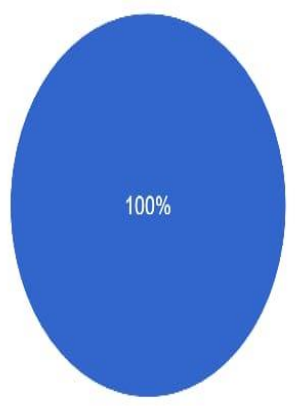

Ya

Tidak

\section{Gambar 9. Persepsi peserta terkait ketercapaian tujuan pembelajaran menggunakan} quizizz

Dalam penggunaan Quizizz sebagai metode evaluasi dari 30 responden, 28 orang atau $93,3 \%$ diantarannya tidak menemui kendala dan 2 Orang atau mencapai $6,7 \%$ menemui kendala saat menggunakan Quizizz. 
Apakah dalam menggunakan Metode Quizizz ini ada kendala yang anda ditemui ?

30 tanggapan

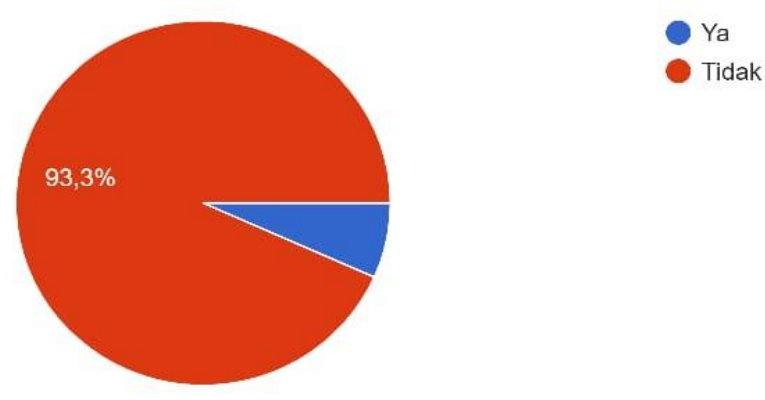

Gambar 10. Persepsi peserta terkait kendala dalam menggunakan quizizz

Dengan metode evaluasi berupa Quizizz ini, menurut 29 responden atau mencapai 96.7\% menyatakan bahwa hasil evaluasi lebih akurat dan transparan dan 1 responden atau mencapai 3.3\% berpendapat bahwa dengan Quizizz hasil evaluasi tidak akurat dan transparan.
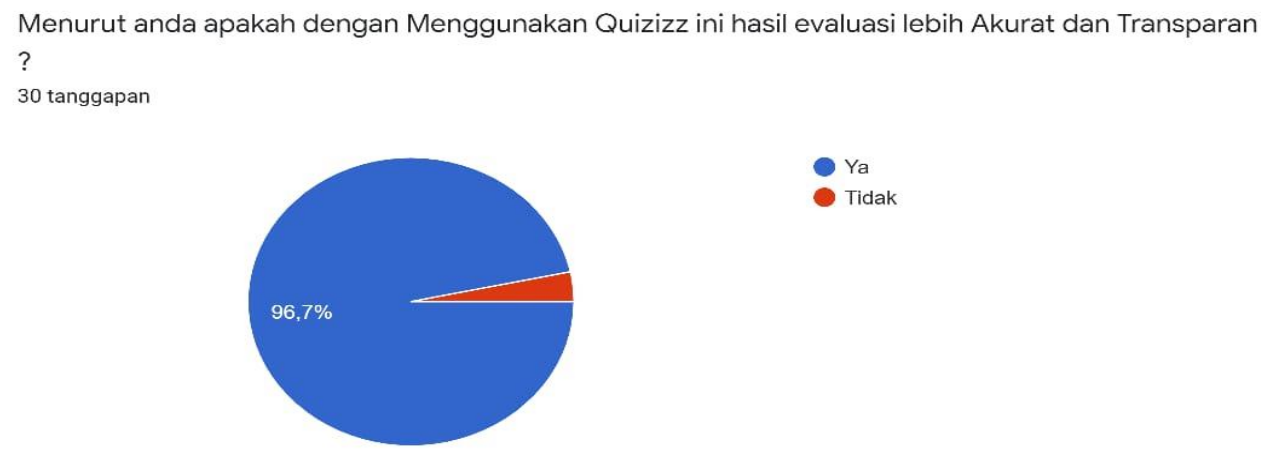

Tidak

\section{Gambar 11. Persepsi peserta tentang akurasi dan transparansi menggunakan quizizz}

Menurut keseluruhan responden sebanyak 30 orang atau mencapai $100 \%$, metode evaluasi dengn Quizizz ini sangat direkomendasikan kepada peserta Pelatihan Dasar yang merupakan generasi milenial.

Menurut anda apakah Penerapan Metode Evaluasi dengan Quiziz sangat direkomendasikan bagi Peserta Pelatihan Dasar yang Adalah Kaum Melenial? 29 tanggapan

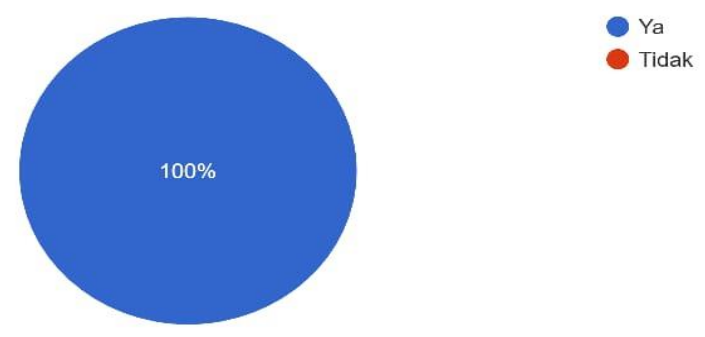

Gambar 12. Persepsi peserta terkait rekomendasi penggunaan apliaksi quizizz 
Tebel 3. Rangkuman persepsi peserta terhadap penggunaan Quizizz

\begin{tabular}{|c|c|c|c|}
\hline No & Persepsi/Pendapat & $\begin{array}{c}\text { Jumlah } \\
\text { Responden }\end{array}$ & Presentasi \\
\hline 1 & $\begin{array}{l}\text { Sebelumnya belum pernah menggunakan } \\
\text { Quizizz. }\end{array}$ & 16 Orang & $53,3 \%$ \\
\hline 2 & $\begin{array}{l}\text { Setuju untuk melakukan evaluasi dengan } \\
\text { Quizizz }\end{array}$ & 30 Orang & $100 \%$ \\
\hline 3 & Quiziz lebih efektif dari metode manual & 28 Orang & $93,4 \%$ \\
\hline 4 & Quiziz lebih efisien dari sisi waktu dan biaya & 27 Orang & $90 \%$ \\
\hline 5 & $\begin{array}{l}\text { Quizizz adalah metode evaluasi yang } \\
\text { mudah dioperasikan }\end{array}$ & 30 Orang & $100 \%$ \\
\hline 6 & $\begin{array}{l}\text { Quizizz adalah metode evaluasi yang } \\
\text { menyenangkan. }\end{array}$ & 30 Orang & $100 \%$ \\
\hline 7 & $\begin{array}{l}\text { Tujuan evaluasi dapat tercapai dengan } \\
\text { menggunakan Quizizz }\end{array}$ & 30 Orang & $100 \%$ \\
\hline 8 & $\begin{array}{l}\text { Tidak menemui } \\
\text { manggunakan atau } \\
\text { Quizizz }\end{array}$ & 28 Orang & $92,3 \%$ \\
\hline 9 & $\begin{array}{l}\text { Hasil evaluasi pembelajaran lebih akurat } \\
\text { dan transparan dengan menggunakan } \\
\text { Quizizz }\end{array}$ & 29 Orang & $96,7 \%$ \\
\hline 10 & $\begin{array}{l}\text { Quizizz sangat direkomendasikan sebagai } \\
\text { metode evaluasi pembelajaran pada } \\
\text { Pelatihan Dasar CPNS yang pesertanya } \\
\text { adalah generasi milenial. }\end{array}$ & 30 Orang & $100 \%$ \\
\hline
\end{tabular}

\section{PEMBAHASAN}

Dalam mewujudkan ASN yang unggul dan kompetitif menuju SMART ASN serta mendukung dalam pelaksanaan tugas dan fungsinya sebagai pelaksana kebijakan publik, pelayan publik serta perekat dan pemersatu bangsa maka ASN dituntut harus memiliki kompetensi dasar yang salah satunya adalah menguasai Teknologi Informasi Komunikasi (TIK). ASN diharapkan tidak gaptek (gagap teknologi) dan dapat mengoperasikan serta memanfaatkan aplikasi - aplikasi produk teknologi informasi komunikasi untuk meningkatkan efektifitas dan efisiensi kinerja dalam rangka pelaksanaan tugas dan fungsi serta dalam pelayanan dan pengabdian kepada masyarakat.

Pegawai negeri sipil sebagai unsur utama sumber daya manusia aparatur memiliki peranan penting dalam menentukan keberhasilan penyelenggaraan pemerintahan dan pembangunan. Sosok PNS yang mampu memainkan peranan tersebut adalah PNS yang memiliki kompetensi yang diindikasikan dari sikap dan perilakunya yang penuh dengan kesetiaan dan ketaatan kepada negara, bermoral dan bermental baik, profesional, sadar akan tanggung jawab sebagai pelayan publik, serta mampu menjadi perekat persatuan dan kesatuan bangsa. Untuk mewujudkan sosok PNS tersebut, perlu dilaksanakan pembinaan melalui jalur pelatihan dasar (Latsar) yang mengarah kepada upaya peningkatan sikap dan semangat pengabdian yang berorientasi pada kepentingan masyarakat, bangsa, negara, dan tanah air, kompetensi teknis, manajerial, dan/atau kepemimpinannya, efisiensi, efektivitas dan kualitas pelaksanaan tugas yang dilakukan dengan semangat kerjasama dan tanggung jawab sesuai dengan lingkungan kerja dan organisasinya. 
Salah satu mata pelatihan dalam agenda nilai-nilai dasar pegawai negeri sipil yakni anti korupsi merupakan mata pelatihan yang memfasilitasi pembentukan nilai - nilai dasar anti korupsi. melalui pembelajaran penyadaran anti korupsi, menjauhi perilaku korupsi, membangun sistem integritas, dan proses internalisasi nilai - nilai dasar anti korupsi, sehingga tujuan yang diharapkan adalah peserta pelatihan dapat mengaktualisasikan sikap dan perilaku amanah, jujur, dan mampu mencegah terjadinya korupsi di lingkungan kerjanya.

Evaluasi pembelajaran merupakan salah satu aspek penting pada proses pembelajaran. Dengan melakukan evaluasi pembelajaran guru dapat mengetahui seberapa berhasil penyampaian materi yang dilakukan saat kegiatan belajar mengajar. Hal ini sesuai dengan pendapat yang disampaikan Edwind \& Gerald W. Brown dalam Supriyadi (2011) bahwa evaluasi pembelajaran merupakan proses untuk menentukan nilai dari segala sesuatu dalam pembelajaran

Quizizz sebagai salah satu Game edukatif, dapat digunakan sebagai media pembelajaran dan metode evaluasi pembelajaran yang diintegrasikan dengan materi atau soal - soal evaluasi diharapkan dapat menciptakan suasana pembelajaran menjadi lebih menarik dan menyenangkan. Hal ini sependapat dengan Henry (2010), yang mengemukakan tentang dampak positif penggunaan game yang salah satunya adalah game menyenangkan dan menghibur serta game memberikan latihan untuk pemecahan masalah dan logika.

Metode evaluasi pada mata pelatihan anti korupsi dilakukan dengan model pre dan post test dengan menggunakan aplikasi Quizizz. Soal pre dan post test dibuat dalam bentuk pilihan ganda sebanyak 10 soal dan 1 soal diberi bobot nilai 1000 , pembobotan ini terdiri dari 2 aspek yakni ketepatan dan kecepatan peserta dalam menjawab setiap soal.

Pre test dilakukan diawal atau sebelum pembelajaran dilakukan, dengan demikian pada pre test ini dapat dikatakan bahwa pemahaman peserta terhadap mata pelatihan anti korupsi ini masih rendah atau bahkan belum ada sama sekali. Setelah dilakukan pre test peserta akan mengikuti pembelajaran dengan berbagai metode yang digunakan oleh widyaiswara/fasilitator, dalam proses pembelajaran inilah diharapkan adanya peningkatan pemahaman peserta terhadap mata pelatihan anti korupsi. Pada proses pembelajaran inilah metode pembelajaran menjadi penting dan menjadi tolak ukur keberhasilan proses pembelajaran. Setelah mengikuti pembelajaran disesi terakhir akan dilakukan kembali evaluasi berupa post test. Keunggulan dari penggunaan aplikasi Quiziz ini sebagai metode evaluasi yaitu peserta masing - masing akan fokus untuk mengejakan soal pre dan post tes, meminimalisir terjadi kecurangan dalam hal ini menyontek jawaban teman, peserta akan terpacu secara spontan untuk menyelesaikan soal-soal yang tersedia, dan hasil pre dan post tes langsung diketahui oleh semua peserta didalam kelas setelah selesai melakukan evaluasi. Disamping keunggulan, dalam penelitian ini ditemukan ada kelemahan atau kekurangan yang dimiliki quizizz yakni penerapan atau penggunaannya quizizz sangat bergantung pada ketersedian jaringan internet.

Evaluasi pembelajaran berbentuk ujian atau penilaian relative dipandang sebagai hal yang menakutkan dan menegangkan bagi siswa maupun peserta pelatihan. Namun dengan melakukan evaluasi pembelajaran melalui Quizizz siswa menganggap kuis tersebut merupakan hal yang menyenangkan dan dapat meningkatkan motivasi untuk belajar.

Dari persepsi peserta pelatihan dasar CPNS terhadap penggunaan quizizz sebagai salah satu metode evaluasi pembelajaran, dapat dijelaskan bahwa metode ini sangat disenangi oleh peserta pelatihan khususnya pelatihan dasar CPNS yang adalah kaum melenial, karena hasil evaluasi diperoleh ketika evaluasi selesai dilakukan.

Berdasarkan penelitian Zhao (2019), menjelaskan bahwa Quizizz dapat membantu siswa focus di pembelajaran dan mengurangi kecemasan mereka terhadap ujian. Menurut Rahman, Kondoy, \& Hasrin (2020), Penggunaan aplikasi kuis dapat dimanfaatkan sebagai media pemberian kuis kepada siswa yang hasilnya sangat signifikan berpengaruh pada motivasi belajar siswa.

Metode Evaluasi dengan quizizz juga, berpengaruh kepada konsentrasi dan motivasi peserta untuk memperoleh hasil post test yang lebih baik dari pre test. Hal ini sejalan degan 
penelitian yang dilakukan oleh Purba (2019), dimana pemanfaatan evaluasi pembelajaran quizizz dapat meningkatkan konsentrasi belajar mahasiswa. Selain itu dalam penerapan metode evaluasi dengan menggunakan quizizz ini, peserta dipacu dengan beberapa indikator keberhasilan evaluasi yakni tingkat pemahaman, kecepatan dan ketepatan dalam menjawab setiap pertanyaan. Ini sesuai dengan penelitian yang dilakukan oleh Salsabila,dkk (2020), bahwa quizizz sebagai game edukatif, memberikan banyak manfaat yang dapat dirasakan dalam pembelajaran, karena media ini menarik dan dapat memotivasi kerja otak dan pengelolaan manajemen waktu.

Metode evaluasi dengan quizizz ini juga berdampak positif bagi widyaiswara atau fasilitator dalam mengetahui keberhasilan pembelajaran. Selain itu, evaluasi dengan quizizz juga sangat membantu widyaiswara atau fasilitator, karena dengan quizizz widyaiswara atau fasilitator tidak perlu untuk mengoreksi atau memeriksa hasil pre dan post test.

Evaluasi pembelajaran dengan menggunakan quizizz ini secara langsung memberikan penguatan terhadap nilai - nilai dasar yang harus dimiliki oleh ASN. Nilai-nilai tersebut antara lain nilai akuntabilitas yakni transparansi dan nilai anti korupsi yakni jujur dan mandiri.

\section{KESIMPULAN}

Berdasarkan hasil penelitian tindakan kelas persepsi peserta tentang penggunaan quizizz sebagai metode evaluasi pada pelatihan dasar CPNS golongan II angkatan IX Tahun 2020 kelas A maka dapat disimpulkan bahwa Quizizz merupakan salah satu metode evaluasi pembelajaran yang sangat menyenangkan, efisien dari segi waktu dan biaya, mudah digunakan dan hasilnya lebih akurat dan serta transparan, hal ini sesuai persepsi peserta pelatihan dasar CPNS golongan II angkatan IX tahun 2020 kelas A, sehingga dapat direkomendasikan bagi widyaiswara atau fasilitator untuk digunakan sebagai metode evaluasi pembelajaran khususnya pada pelatihan dasar CPNS yang pesertanya merupakan generasi milenial. Implikasi hasil penelitian ini bagi widyaiswara maupun fasilitator sebagai bahan referensi dan acuan dalam memilih dan menerapkan metode evaluasi pembelajaran yang menyennagkan dan sesuai dengan karakteristik peserta khususnya pada pelatihan dasar misalnya khahoot sehingga diharapkan kedepannya akan ada penelitian tindakan kelas yang lainnya misalnya metode evaluasi pembelajaran dengan menggunakan Khahoot atau bahkan media pembelajaran berupa google classroom.

\section{REFERENSI}

Arikunto., Suharjono., Supardi. (2017). Penelitian Tindakan Kelas, Jakarta Bumi Aksara.

Suharsono, A. (2020) Penggunaan Aplikasi Quizizz dalam pelatihan Dasar CPNS Kemenkeu Generasi Milenial. Jurnal Paedagoria, 11(1): 60 - 66

Hasibuan, J.K (2016). Peranan Pengelolaan Kelas Dalam Menciptakan Suasana Pembelajaran Yang Menyenangkan dan Meningkatkan Efektifitas Pembelajaran Diklat. ESJ, 5(2) : 84-89.

Hamzah, J.K. (2016), Kompetensi WIdyaiswara dan Kualitas Diklat. Jurnal IImu Pendidikan, Keguruan dan Pembelajaran, 1(2):111 - 118.

Henry, S. (2010). Cerdas dengan Game. Jakarta: PT Gramedia Pustaka Utama. Aini. Y.I. (2019). Pemanfaatan Media Pembelajaran Quizizz Untuk Pembelajaran Jenjang Pendidikan Dasar Dan Menengah Di Bengkulu. Kependidikan, 2(25).

Mohammad Syaifulloh. (2020), Pengembangan Alat Evaluasi Menggunakan Aplikasi Quizizz pada Pembelajaran IPS Terpadu di MTS Negeri Malang. Tesis, Universitas Islam Negeri Maulana Malik Ibrahim.

Rahmania Rahman dkk. (2020), Penggunaan Aplikasi Quizizz Sebagai Media Pemberian Kuis Dalam Meningkatkan Motivasi Belajar Mahasiswa.

Noor, S. (2020) Penggunaan Quizizz Dalam Penilaian Pembelajaran Pada Materi Ruang 
Lingkup Biologi Untuk Meningkatkan Hasil Belajar Siswa Kelas X. SMA Negeri 7 Banjarmasin. Jurnal Pendidikan Hayati, 6(1): 1-7.

Nada, Q, Yasin, M, Arief, KM. (2020). The Effect Of Google Classroom Learning Media And Emotional Intelligence On The Results Of Learning History Indonesia. Jurnal Akademika, 9(02): 17-28.

Peraturan Kepala Lembaga Administrasi Negara Nomor 12 Tahun (2018). Pelatihan Dasar Calon Pegawai Negeri Sipil.

Purba, L.S.L. (2019). Peningkatan Konsentrasi Belajar Mahasiswa Melalui Pemanfaatan Evaluasi Pembelajaran Quizizz Pada Mata Kuliah Kimia Fisika. Jurnal Dinamika Pendidikan (JDP), 12(1): 29-39.

Rahman, R., Kondoy, E., \& Hasrin, A. (2020). Penggunaan Aplikasi Quizziz Sebagai Media Pemberian Kuis Dalam Meningkatkan Motivasi Belajar Mahasiswa. Jurnal IImu Sosial Dan Pendidikan (JISIP), 4(3): 60-66.

Salsabila, U.H., Habiba, I.S., Amanah, I.L., Istiqoma, N.A., Difani, S. (2020).

Pemanfaatan Aplikasi Quizizz Sebagai Media Pembelajaran Di Tengah Pandemi Pada Siswa SMA. Jurnal IImiah IImu Terapan Universitas Jambi (JIITUJ), 4(2):163-172.

Supriadi. G. (2011). Pengantar dan Teknik Evaluasi Pembelajaran. Malang. Indonesia.

Undang - Undang Nomor 5 Tahun (2015), tentang Aparatur Sipil Negara.

Wibawa, R.P., Astuti, R.I., dan Pangestu, B.A. (2019). Smartphone-Based Application "quizizz" as a Learning Media. Jurnal Dinamika Pendidikan, 14(2): 244-253.

http://nancyradjah31.blogspot.com/2018/05/softwere-pembelajaran-online.html

https://pojok6.id/2019/12/15/asn-berperan-penting-dalam-keberhasilan

penyelenggaraan-pemerintahan/ 